\title{
Effects of Cover Type and Harvest Date on Yield, Quality and Cost-Effectiveness of Early Potato Cultivation
}

\author{
Katarzyna Rębarz • Franciszek Borówczak • Renata Gaj • \\ Tomasz Frieske \\ Published online: 12 March 2015 \\ (C) The Author(s) 2015. This article is published with open access at Springerlink.com
}

\begin{abstract}
The aim of this study was to evaluate the effects of cover type (control, agro-textile or perforated plastic film) and harvest date (60 or 75 days after planting and at full physiological maturity) on the yield, quality and cost-effectiveness of early harvest potato cultivation. The study was conducted in the years 2008-2011, at the Gorzyń Experimental-Education Laboratory for Soil and Plant Cultivation, Gorzyń Branch, part of the University of Natural Sciences in Poznań. The experiment was set up in a split-plot randomized block design with four replications. Covers increased the total and marketable tuber yields at early harvest dates, in particular on the 60th day after planting, compared to the reference. Tubers cultivated under covers were also found to contain higher amounts of dry matter and starch than those which were not covered. The proportion of tuber fractions with a diameter between 4.6 and $5.5 \mathrm{~cm}$ and above in the total yield was found to be strongly dependent on cover type. The proportion of these fractions was significantly lower under plastic film than under Agro-textile. Over the 3 years cycle, high gross margins were achieved on the 60th and 75th days after planting with perforated film and agro-textile.
\end{abstract}

Resumen El propósito de este estudio fue evaluar los efectos del tipo de cobertura (testigo, agrotextil, o plástico perforado) y fecha de cosecha (60 o 75 días después de la siembra y a madurez fisiológica total) sobre el rendimiento, calidad y costo-efectividad en el cultivo de papa de cosecha temprana. El estudio se desarrolló en los años 2008-2011, en el Laboratorio Experimental de Educación para Suelo y Cultivo

\footnotetext{
K. Rębarz $(\bowtie) \cdot F$. Borówczak $\cdot$ T. Frieske

Department of Agronomy, University of Life Sciences, Dojazd 11, 60-632 Poznań, Poland

e-mail: rebarz@up.poznan.pl

R. Gaj

Department of Agricultural Chemistry and Environmental Biogeochemistry, Poznań, University of Life Sciences, Wojska Polskiego 71 F, 60-625 Poznań, Poland
}

de Plantas Gorzyń, rama de Gorzyń, perteneciente a la Universidad de Ciencias de la Vida en Poznań. El experimento se estableció en un diseño de bloques divididos al azar con cuatro repeticiones. El propósito del trabajo fue evaluar los efectos de tipo de cobertura (testigo, agro-textil, o capa de plástico perforada) y fechas de cosecha (60 y 75 días después de la siembra, a madurez fisiológica completa de los tubérculos) sobre rendimientos y calidad de tubérculos, así como en los resultados económicos del cultivo de papa para cosecha temprana. Las coberturas aumentaron los rendimientos de tubérculo total y comercial en las fechas de cosecha temprana, en particular a los 60 días después de la siembra, al compararse con la referencia. De la misma manera, se encontró que los tubérculos bajo cobertura contenían mayores cantidades de materia seca y almidón que los no cubiertos. El margen alto de retribución neta se alcanzó a los 60 y 75 días después de la siembra, en los tratamientos con plástico perforado y agrotextil, que fueron usados en un ciclo de tres años.

Keywords Potatoes · Agro-textile $\cdot$ Perforated film · Yield · Tuber quality $\cdot$ Cost-effectiveness

\section{Introduction}

In Poland, early harvest cultivation of potatoes is currently conducted on an area of around 30-40 thousand hectares. Achieving the earliest possible marketable yield is of vital importance for such cultivation (Harasim et al. 2004; Wadas and Sawicki 2005). According to the Regulation of the Minister of Agriculture and Rural Development dated 29 October 2003, concerning specific requirements for the commercial quality of potatoes, the commercial fraction of early potatoes is defined as tubers of over $28 \mathrm{~mm}$ in diameter. Early potatoes in Poland are usually marketable on the 60th or 75th day after planting. Lower yields of tubers harvested on these dates are usually offset by higher selling prices (Sawicka 1998). Later 
dates increase yields, with a corresponding lowering of prices. Potato cultivation for early cropping involves considerable risk, due to the possibility of early frosts in the initial period of growth, which may cause significant damage to entire plantations. To minimize such risks, coverings are used, including agro-textiles or perforated plastic films (Collingwood and Frost 1988; Friessleben 1984; Jenkins and Gillison 1995; Wadas and Sawicki 2005). Coverings not only provide protection against early frosts and temperatures which can drop to $-5{ }^{\circ} \mathrm{C}$, but also against other unfavorable climatic events, such as hail, strong winds and heavy rains. Such converings can also advance crop emergence by 3 to 8 days, and increase both total and commercial yields (Bizer 1994; Cholakov and Nacheva 2009; Demmler 1998; Dvoř́ák and Hamouz 2008; Harasim et al. 2004; Rębarz 2013; Wadas and Sawicki 2009).

Tuber chitting is a further measure that can encourage the faster cultivation of crops. Although the application of covers and tuber chitting increases the cost of potato production, it may be justified as long as the value of the increased yield exceeds the expense incurred. The use of covers increases the direct cost of early potato production by between 40 and $124 \%$ when compared with non-covered cultivation, with the cost of agro-textile adding around 30 to $50 \%$ to the direct cost (Harasim et al. 2004; Wadas and Sawicki 2005, 2009). The cost of agro-textile can be spread across two or three seasons of use, which significantly decreases its impact on the cost of potato production.

The objective of this study was to evaluate the effects of cover type (agro-textile or perforated plastic film) on yield and quality of first early potato tubers as well as on the cost-effectiveness of cultivation at various harvest dates. It was assumed that advancing potato growth provides higher and more cost-effective tuber yields in early harvests, without immediate deterioration of tuber quality.

\section{Materials and Methods}

Field experiments were conducted at the Gorzyń Experimental-Education Laboratory for Soil and Plant Cultivation, Gorzyń Branch, part of the University of Life Sciences in Poznań (52.6 N, 15.9E) over the years 2008-2011, in a split-plot randomized block design with four replications. The experimental factors in the study included:

\section{Cover type:}

- potatoes grown without cover (control treatment),

- potatoes covered with agro-textile - P19,

- potatoes covered with perforated plastic film;
2. Harvest date:

- 60 days after planting,

- 75 days after planting,

- at full physiological maturity.

Seed tubers of Arielle (a very early potato cultivar) were used in the experiment. The potatoes were grown in a fourplot crop rotation design: potato - spring barley - narrowleafed lupin - winter wheat. In each year of the experiment, the potatoes were planted in the first 10 days of April. Phosphorus and potassium fertilization was applied in autumn before winter plowing. The soil used was classified in the IVa group of Luvisols, i.e., as a very-good-rye-soil complex type. The humus content was in a range from 0.96 to $1.60 \%$. The soil phosphorus content was high, and the level of available potassium was average. Phosphorus was introduced into the soil as an enriched superphosphate at a dose of $42.4 \mathrm{~kg} \mathrm{P} \cdot \mathrm{ha}^{-1}$, while potassium in the form of potassium chloride was added with a dose of $124.5 \mathrm{~kg} \mathrm{~K} \cdot \mathrm{ha}^{-1}$. Nitrogen in the form of ammonium nitrate was added at a dose of $100 \mathrm{~kg} \mathrm{~N} \cdot \mathrm{ha}^{-1}$ directly before tuber planting. The seed tubers were chitted before planting over a 6 weeks period, then planted with row spacing of $30 \mathrm{~cm}$ and $70 \mathrm{~cm}$. The tubers were not pretreated. After planting, Sencor 70 WG herbicide was applied to the soil, and the rows were covered with agro-textile and perforated plastic film. When the plants reached around $20 \mathrm{~cm}$ in height, the agrotextiles (Pegas Agro P-19) and perforated plastic films were removed. Depending on the weather during the vegetation period, the plants were sprayed once or twice with fungicide against potato blight and once with an insecticide. The surface area of the sampling plots was kept at $21 \mathrm{~m}^{2}(1.4 \times 15 \mathrm{~m})$.

The structure of the tuber yield from $5 \mathrm{~kg}$ of initial tubers was determined on the 60th day, and on the 75th day in the case of $10 \mathrm{~kg}$ of initial tubers and for tubers at full physiological maturity. The proportions of the tuber fractions in the following transverse diameter classes were determined in the total yield: below $2.8 \mathrm{~cm}, 2.8-3.5 \mathrm{~cm}, 3.6-4.5 \mathrm{~cm}, 4.6-5.5 \mathrm{~cm}$ and above $5.5 \mathrm{~cm}$. Commercial tuber yields were determined taking into account the proportion of tubers with a diameter greater than $2.8 \mathrm{~cm}$ for potatoes harvested on the 60th and 75th days after planting, while in the phase of full physiological maturity the commercial fraction comprised tubers over $3.5 \mathrm{~cm}$ in diameter.

The dry matter content in tuber samples taken from each of the sampling plots was determined using the dry-weight method. Cleaned and fragmented tubers were dried at $105^{\circ} \mathrm{C}$ until the weight became constant. The starch content in tubers harvested on the 75th day after planting and in those at full physiological maturity was determined using the Reiman-Parow scale. The average amount of starch was calculated from the values in samples taken from each of the sampling plots.

The mean prices of production in the year 2014 were used to calculate the cost of potato cultivation. In order to calculate the 
Table 1 Rainfall and temperature during the potato growth period in 2008-2011

\begin{tabular}{lrrrrr}
\hline \multirow{2}{*}{ Years } & \multicolumn{2}{l}{ Months } & & & \\
\cline { 2 - 6 } & IV & \multicolumn{1}{c}{ V } & VI & VII & IV-VII \\
\hline Rainfall (mm) & & & & & \\
$1951-2006$ & 50.3 & 53.1 & 59.8 & 75.6 & 238.8 \\
2008 & 167.7 & 8.9 & 34.6 & 73.8 & 285.0 \\
2009 & 13.7 & 70.9 & 78.9 & 82.8 & 246.3 \\
2010 & 36.4 & 80.8 & 3.1 & 96.6 & 216.9 \\
2011 & 8.3 & 25.5 & 4.9 & 176.3 & 259.0 \\
Temperature (C) & & & & & \\
$1951-2006$ & 8.0 & 14.4 & 17.0 & 18.6 & 14.5 \\
2008 & 8.1 & 14.7 & 18.2 & 23.1 & 16.0 \\
2009 & 10.9 & 13.5 & 15.7 & 19.3 & 14.8 \\
2010 & 9.1 & 12.1 & 17.7 & 21.2 & 15.0 \\
2011 & 11.0 & 14.2 & 18.3 & 17.9 & 15.4 \\
\hline
\end{tabular}

value of the yields as well as the cost-effectiveness of potato cultivation, selling prices were set at $2000 \mathrm{PLN} \mathrm{t}^{-1}$ for tubers harvested on the 60th day after planting, $1000 \mathrm{PLN} \mathrm{t}^{-1}$ for potatoes harvested on the 75th day after planting, and 500 PLN $t^{-1}$ for tubers at full physiological maturity. Since selling prices vary between years, the simulation is was calibrated to calculate the gross margin from 1 ha of potato cultivation at the different harvest dates. The gross margin was calculated according to the EU standards (Augustyńska-Grzymek et al. 2000), as the difference between the production value (value of the commercial yield, SAP (single area payment) - 830.30 PLN ha ${ }^{-1}$, compensatory payment for seed tuber material -500 PLN t ${ }^{-1}$ ) and the direct costs.

The results were processed statistically using factorial analysis of variance (ANOVA). The significance level of the
Table 3 Effects of cover type and harvest date on total yield of tubers, with mean in the years 2008-2011 ( $\left.\mathrm{t} \mathrm{ha}^{-1}\right)$

\begin{tabular}{lcccc}
\hline Cover type (A) & \multicolumn{2}{c}{ Harvest date - days after planting (B) } & \multirow{2}{*}{ Mean } \\
\cline { 2 - 4 } & 60 & 75 & Full maturity & \\
\hline Control treatment & 7.89 & 13.04 & 18.88 & 13.27 \\
Agro-textile & 9.61 & 16.02 & 19.00 & 14.88 \\
Plastic film & 10.28 & 14.55 & 16.31 & 13.71 \\
Mean & 9.26 & 14.54 & 18.06 & - \\
LSD & $\alpha=0.05$ & $\mathrm{~A}-1.197 ; \mathrm{B}-0.857 ; \mathrm{AxB}_{\mathrm{I}}-1.484 ; \mathrm{AxB}_{\mathrm{II}}-1.703$ \\
\hline
\end{tabular}

differences was measured using Tukey's test at $\alpha=0.05$. $\mathrm{LSD}_{\mathrm{I}}$ and $\mathrm{LSD}_{\mathrm{II}}$ were calculated in line with the interpretation of interactions for factorial experiments, where $\mathrm{LSD}_{\mathrm{I}}$ is the comparison of means of factor $\mathrm{B}$ at the same level of factor $\mathrm{A}$, and $\mathrm{NIR}_{\text {II }}$ is the comparison of the means of factor $A$ at the same or a different level of factor B.

The weather patterns varied between the study years (Table 1). The average air temperatures in the months (IVVII) of the vegetation season were above the multi-annual averages, except in May and June 2009, May 2010 and May and July 2011 , when these values were lower by $0.9,1.3,2.3$, 0.2 and $0.7^{\circ} \mathrm{C}$ respectively.

The average rainfall during the vegetation period was higher than the multi-annual average, except in the year 2010. Potato yields were significantly affected by an uneven distribution of precipitation in the year 2010. Low precipitation was observed in May and June of the year 2008, as well as in June of the year 2010. In the year 2009, precipitation below the multi-annual average occurred only in April, while in the remaining vegetation months there was above average rainfall. In the year 2011, low precipitation was observed in the first 3 months of potato growth. Precipitation deficit, especially in May and the first

Table 2 Effect of weather conditions on potato yields in the study years $\left(\mathrm{t} \mathrm{ha}^{-1}\right)$

\begin{tabular}{|c|c|c|c|c|c|c|c|c|c|}
\hline \multirow[t]{3}{*}{ Factor } & \multirow[t]{3}{*}{ Factor level } & \multicolumn{8}{|l|}{ Years } \\
\hline & & \multicolumn{2}{|l|}{2008} & \multicolumn{2}{|l|}{2009} & \multicolumn{2}{|l|}{2010} & \multicolumn{2}{|l|}{2011} \\
\hline & & $\mathrm{TY}^{*}$ & $\mathrm{CY}^{* *}$ & $\mathrm{TY}^{*}$ & $\mathrm{CY}^{* *}$ & $\mathrm{TY}^{*}$ & $\mathrm{CY}^{* *}$ & $\mathrm{TY}^{*}$ & $\mathrm{CY}^{* *}$ \\
\hline \multirow[t]{3}{*}{ Cover type } & Control treatment & 10.83 & 10.16 & 17.28 & 16.67 & 20.08 & 19.04 & 4.89 & 4.10 \\
\hline & Agro-textile & 12.48 & 11.74 & 15.26 & 14.90 & 23.92 & 22.59 & 7.85 & 7.13 \\
\hline & Plastic film & 13.75 & 12.98 & 9.87 & 9.41 & 24.25 & 22.78 & 6.98 & 6.12 \\
\hline $\mathrm{LSD}_{\alpha=0.05}$ & & 0.956 & 0.915 & 2.99 & 2.899 & 1.53 & 1.45 & 0.978 & 0.846 \\
\hline \multirow{3}{*}{$\begin{array}{l}\text { Harvest date - days } \\
\text { after planting }\end{array}$} & 60 & 10.35 & 9.28 & 7.26 & 6.29 & 15.69 & 13.88 & 3.75 & 2.63 \\
\hline & 75 & 12.36 & 11.75 & 15.45 & 15.12 & 24.21 & 22.78 & 6.13 & 5.27 \\
\hline & Full maturity & 14.34 & 13.86 & 19.71 & 19.57 & 28.37 & 27.76 & 9.85 & 9.45 \\
\hline $\operatorname{LSD}_{\alpha=0.05}$ & & 1.027 & 1.027 & 2.099 & 2.097 & 2.540 & 2.591 & 1.075 & 1.074 \\
\hline
\end{tabular}

${ }^{*}$ TY total yield; ${ }^{* *}$ CY commercial yield 
Table 4 Effects of cover type and harvest date on commercial yield of tubers, with mean in the years 2008-2011 $\left(\mathrm{t} \mathrm{ha}^{-1}\right)$

\begin{tabular}{lcccc}
\hline Cover type (A) & \multicolumn{2}{l}{ Harvest date - days after planting (B) } & Mean \\
\cline { 2 - 4 } & 60 & 75 & Full maturity & \\
\hline Control treatment & 6.61 & 12.34 & 18.54 & 12.50 \\
Agro-textile & 8.46 & 15.22 & 18.59 & 14.09 \\
Plastic film & 8.99 & 13.63 & 15.86 & 12.82 \\
Mean & 8.02 & 13.73 & 17.66 & - \\
LSD ${ }_{\alpha=0.05}$ & $\mathrm{~A}-1.193 ; \mathrm{B}-0.865 ; \mathrm{AxB}_{\mathrm{I}}-1.499 ; \mathrm{AxB}_{\mathrm{II}}-1.709$ \\
\hline
\end{tabular}

20 days of June -i.e., the critical period for potato growth - was reflected in the size of the tuber yields.

\section{Results}

Both total and commercial yields of tubers were largely determined by the hydrothermal conditions in the study years (Table 2). The maximum potato yields were obtained in 2010, with beneficial rainfall in May and July. Much lower yields were obtained in the years 2008 and 2009, while the lowest were noted in 2011. In all of the study years, the highest tuber yields were obtained from cultivations under agro-textile and perforated plastic film covers. A lower yield from a cultivation under cover was obtained only in 2009, when the loss of commercial yield under agro-textile was $10.6 \%$ and that under perforated plastic film was $43.5 \%$.

Both the highest total and commercial yields were obtained from potato cultivation under agro-textile (Tables 3 and 4), while the total yield did not differ significantly from that harvested from plots covered with perforated plastic film (Table 3). The total and commercial yields harvested were lowest from the reference plot but did not differ significantly from those harvested from cultivation under plastic film. A relationship was noted between the cover type and harvest time. This was reflected in the tuber yield size, with higher

Table 5 Effects of cover type and harvest date on the number of tubers found under a single plant, with mean in the years 2008-2011 (no)

\begin{tabular}{lcccr}
\hline Cover type (A) & \multicolumn{2}{l}{ Harvest date - days after planting (B) } & \multirow{2}{*}{ Mean } \\
\cline { 2 - 4 } & 60 & 75 & Full maturity & \\
\hline Control treatment & 10.60 & 9.47 & 9.31 & 9.79 \\
Agro-textile & 12.60 & 10.60 & 10.37 & 11.19 \\
Plastic film & 11.66 & 10.82 & 10.20 & 10.89 \\
Mean & 11.62 & 10.30 & 9.96 & - \\
LSD $_{\alpha=0.05}$ & $\mathrm{~A}-0.867 ; \mathrm{B}-$-n.s.; $\mathrm{AxB}_{\mathrm{I}}$-n.s.; $\mathrm{AxB}_{\mathrm{II}}$-n.s. & \\
\hline
\end{tabular}

n.s., not significant differences
Table 6 Effects of cover type and harvest date on the weight of tubers found under a single plant, with mean in the years 2008-2011 (g)

\begin{tabular}{llllc}
\hline Cover type (A) & \multicolumn{2}{c}{ Harvest date - days after planting (B) } & \multirow{2}{*}{ Mean } \\
\cline { 2 - 4 } & 60 & 75 & Full maturity & \\
\hline Control treatment & 185.23 & 301.17 & 444.92 & 310.44 \\
Agro-textile & 242.81 & 322.23 & 440.75 & 335.26 \\
Plastic film & 238.37 & 311.04 & 398.83 & 316.08 \\
Mean & 222.14 & 311.48 & 428.17 & - \\
LSD $_{\alpha=0.05}$ & $\mathrm{~A}-32.499 ; \mathrm{B}-23.043 ; \mathrm{AxB}_{\mathrm{I}}-39.912 ; \mathrm{AxB}_{\mathrm{II}}-46.016$ \\
\hline
\end{tabular}

increments of the total and commercial yields harvested from the reference plots, compared with those from plots covered with agro-textile and plastic film. In the case of total yield, the increments attained between the harvest time on 60th and 75th days after planting and between the 75th day after planting and full tuber maturity were respectively: 5.15 and $5.84 \mathrm{tha}^{-1}$ for the reference, 6.41 and $2.98 \mathrm{t} \mathrm{ha}^{-1}$ for plots covered with agro-textile and 4.27 and $1.76 \mathrm{tha}^{-1}$ for plots covered with plastic film. In the case of commercial yield, the increments were: 5.73 and $6.2 \mathrm{t} \mathrm{ha}^{-1}, 6.76$ and $3.37 \mathrm{tha}^{-1}$ and 4.64 and $2.23 \mathrm{t} \mathrm{ha}^{-1}$, respectively. Higher tuber yields were harvested on the 60th day after planting in the covered potato cultivation as compared to the reference. Moreover, for the cultivation under cover, an increase in yield was found which corresponded to the delay in the harvest time.

The greatest number of tubers from under a single potato plant was found in the cultivation covered with agro-textile. However, the number of tubers did not significantly differ from that obtained from the cultivation covered with plastic film (Table 5).

No effect of cover type was observed on the weight of tubers found under a single potato plant. However, the weight increased with the delay in harvesting (Table 6). A relationship was found between the cover type and harvest time. The highest weight increments were observed in the reference plot, at $115.9 \mathrm{~g}$ between the 60th and 75th days after planting, and $143.8 \mathrm{~g}$ between the 75 th day after planting and the attainment of full maturity. Lower increments of tuber weights were noted in the plot covered with agro-textile, at 79.4 and $118.5 \mathrm{~g}$ respectively, while the lowest were measured in potatoes cultivated under plastic film, at 72.7 and $87.8 \mathrm{~g}$, respectively. A relationship between the cover type and the harvesting time showed higher weight increments in the control treatment as compared to the plots covered with agro-textile or plastic film. The weight increments of tubers in the control cultivation were $115.9 \mathrm{~g}$ between the 60th and 75th days from planting and up to $256.3 \mathrm{~g}$ between harvesting in the 75th day and the date of full maturity. The use of agro-textile resulted in lower weight increments and gave increments of $79.4 \mathrm{~g}$ and $118.5 \mathrm{~g}$ respectively. The increments were lowest with the plastic film cover, at only $72.7 \mathrm{~g}$ and $87.8 \mathrm{~g}$. 
Table 7 Effects of cover type and harvest date on the proportion of specific tuber mass fractions in the total yield, with mean in the years 2008-2011 (\%)

\begin{tabular}{|c|c|c|c|c|c|c|}
\hline \multirow[t]{2}{*}{ Factor } & \multirow[t]{2}{*}{ Factor level } & \multicolumn{5}{|c|}{ Fractions of tubers in diameter class $(\mathrm{cm})$} \\
\hline & & $<2.8$ & $2.8-3.5$ & $3.6-4.5$ & $4.6-5.5$ & $>5.5$ \\
\hline \multirow[t]{3}{*}{ Cover type } & Control treatment & 11.50 & 45.38 & 32.02 & 9.86 & 1.24 \\
\hline & Agro-textile & 7.23 & 42.81 & 36.58 & 12.18 & 1.21 \\
\hline & Plastic film & 8.37 & 47.63 & 35.63 & 7.76 & 0.60 \\
\hline $\mathrm{LSD}_{\alpha=0.05}$ & & 1.593 & 3.070 & 2.870 & 1.200 & 0.383 \\
\hline \multirow[t]{3}{*}{ Harvest date - days after planting } & 60 & 17.28 & 63.57 & 18.11 & 1.03 & 0.00 \\
\hline & 75 & 7.19 & 43.71 & 40.89 & 7.98 & 0.22 \\
\hline & Full maturity & 2.63 & 28.53 & 45.22 & 20.78 & 2.83 \\
\hline $\operatorname{LSD}_{\alpha=0.05}$ & & 1.404 & 2.439 & 2.324 & 1.454 & 0.543 \\
\hline
\end{tabular}

The highest proportion of tubers below $2.8 \mathrm{~cm}$ in diameter in the total yield was found in the reference plot, while tubers of $2.8-3.5 \mathrm{~cm}$ in diameter accounted for the largest fraction in the potato cultivation under plastic film (Table 7). The proportion of these fractions decreased with the delay in harvest time. The share of 3.6-4.5 cm tubers in the total yield was higher under both agro-textile and plastic film, while that of $4.6-5.5 \mathrm{~cm}$ tubers only was highest for cultivation under agro-textile.

The proportions of the above fractions in the total yield increased with the delay in the harvest time. The fraction of tubers above $5.5 \mathrm{~cm}$ in diameter accounted for a higher share in the reference cultivation and under agro-textile than in the cultivation under plastic film. This fraction was not present in the yield from the first harvest date, i.e., on the 60th day after planting. Tubers above $5.5 \mathrm{~cm}$ in diameter were present only on the second and third harvest dates.

The contents of dry mass and starch were higher in potato tubers cultivated under both agro-textile and perforated plastic film covers than in potatoes cultivated without coverings (Tables 8 and 9). The dry mass and starch contents were greatest on the second harvest date, i.e., on the 75th day after planting.

Cost analysis shows that covers and seed tubers accounted for the highest share of production expenses (Table 10). Tuber chitting and the application of agro-textile and perforated plastic film covering resulted in a high gross margin from potatoes

Table 8 Effects of cover type and harvest date on the content of potato tuber dry mass, with mean in the years 2008-2011 (\%)

\begin{tabular}{llllc}
\hline Cover type (A) & \multicolumn{2}{l}{ Harvest date - days after planting (B) } & \multirow{2}{*}{ Mean } \\
\cline { 2 - 4 } & 60 & 75 & Full maturity \\
\hline Control treatment & 18.09 & 22.01 & 19.98 & 20.03 \\
Agro-textile & 19.41 & 21.60 & 20.48 & 20.50 \\
Plastic film & 19.40 & 22.36 & 20.38 & 20.72 \\
Mean & 18.97 & 21.99 & 20.28 & - \\
LSD $_{\alpha=0.05}$ & $\mathrm{~A}-0.427 ; \mathrm{B}-0.396 ; \mathrm{AxB}_{\mathrm{I}}-0.687 ; \mathrm{AxB}_{\mathrm{II}}-0.705$ \\
\hline
\end{tabular}

harvested on the 60th and 75th days after planting (Table 11). The application of agro-textile covering decreased the gross margin as compared to the reference, while in the case of perforated plastic film the direct costs incurred were higher than the production value obtained.

\section{Discussion}

The weather during the potato growing season is one of the most important factors affecting potato yield and tuber quality (Gładysiak and Borówczak 1996; Rębarz and Borówczak 2006). Hydrothermal conditions were of decisive importance for the size of total and commercial tuber yields during our 4 years study. The maximal yields of potatoes were obtained in the year 2010, when moisture conditions were most favorable for potato growth. Much lower yields were obtained in the subsequent years, and the lowest noted in 2011. In the last year of the study, the late frosts in May $\left(-7^{\circ} \mathrm{C}\right)$ caused plant injuries and were the main cause for the decreased yields. Low rainfall in the first months of the growing season (April, May and first half of June) also contributed to plant drying. Intense precipitation in July then caused tuber rot, further diminishing the yield. These results indicate a significant relationship

Table 9 Effects of cover type and harvest date on the starch content in potato tubers, with mean in the years 2008-2011 (\%)

\begin{tabular}{llccc}
\hline Cover type (A) & \multicolumn{2}{l}{ Harvest date - days after planting (B) } & Mean \\
\cline { 2 - 4 } & 60 & 75 & Full maturity & \\
\hline Control treatment & 11.71 & 15.00 & 13.16 & 13.29 \\
Agro-textile & 12.52 & 15.44 & 13.52 & 13.83 \\
Plastic film & 12.75 & 15.37 & 13.91 & 14.01 \\
Mean & 12.32 & 15.27 & 13.53 & - \\
LSD & & $\mathrm{A}-0.05$ & $-0.330 ; \mathrm{B}-0.270 ; \mathrm{AxB}_{\mathrm{I}}$-n.s.; $\mathrm{AxB}_{\mathrm{II}}-$-n.s. & \\
\hline
\end{tabular}

n.s., non-significant differences 
Table 10 Direct costs of early potato cultivation using agro-textile and perforated film covering over 3 years per one hectare

\begin{tabular}{|c|c|c|c|c|c|}
\hline \multirow[t]{3}{*}{ Items } & \multirow[t]{3}{*}{ Number } & \multirow[t]{3}{*}{ Unit price in PLN } & \multicolumn{3}{|c|}{ Direct cost for respective harvest dates, on 60th and 75 th days after planting } \\
\hline & & & \multirow[t]{2}{*}{ PLN } & \multicolumn{2}{|c|}{$\%$ share of cost accounted by cultivation under: } \\
\hline & & & & Agro-textile & *Plastic film \\
\hline Seed tubers & $3 \mathrm{t}$ & 1500 & 4500 & 54.05 & 53.00 \\
\hline $34 \%$ Ammonium nitrate & $100 \mathrm{~kg}$ & 4.25 & 425 & 5.11 & 5.00 \\
\hline Enriched superphosphate $40 \%$ & $100 \mathrm{~kg}$ & 4.55 & 455 & 5.47 & 5.35 \\
\hline Potassium salt $60 \%$ & $150 \mathrm{~kg}$ & 3.18 & 477 & 5.72 & 5.62 \\
\hline Plant protection means & - & - & 400 & 4.81 & 4.72 \\
\hline Tuber chitting & & 400.0 & 400 & 4.81 & 4.72 \\
\hline Agro-textile & & 5000 & 1667 & 20.03 & - \\
\hline *Perforated plastic film & & *5500 & *1833 & - & 21.59 \\
\hline Total direct costs & - & - & $8324 / /^{*} 8490$ & 100 & $* 100$ \\
\hline
\end{tabular}

* applies only to perforated plastic film

between potato yields and weather patterns, which is particularly pronounced under conditions of cultivation on light soils with limited water retention capacity.

In order to advance potato growth and enable early harvests, seed tubers are often subjected to chitting and plantations are covered with agro-textile or perforated plastic film (Hamouz et al. 2005; Rębarz 2013; Wadas 2003, 2007; XiaoLing et al. 2005; Xiao-Yan et al. 2010). In our study, the highest tuber yields, both total and commercial, were achieved in a cultivation under agro-textile. However, these yields did not differ significantly from those obtained under plastic film. Moreover, they were only slightly higher than yields harvested on the reference plot. The higher yield obtained from potato cultivation under agro-textile cover was largely a function of the higher tuber dry mass and the number of tubers under a single plant (Demmler 1998; Dvořák and Hamouz 2008; Cholakov and Nacheva 2009).

In the cultivation of potatoes for early cropping, it is of vital importance to achieve the earliest possible commercial yield, which is defined as the proportion of marketable tubers (transverse diameter $>2.8 \mathrm{~cm}$ ). The cultivation of potatoes under agro-textile cover in our study enabled an increase in the proportion of marketable tubers in the total yield. Similar results were obtained by Harasim et al. (2004); Prośba-Białczyk and Mydlarski (1998) and Wadas and Sawicki (2005).

Changes in the content of tuber dry mass, which is also related to the starch content, may be important in terms of the nutritional value of potatoes. Both are dependent on agrotechnical and environmental factors, but primarily on the potato cultivar (Shock et al. 1993; Storey and Davies 1992; Yusuph et al. 2003; Zaag 1980; Zimnoch-Guzowska and Flis 2006). In our study, as in studies by Jabłońska-Ceglarek and Wadas (2005); Wadas et al. (2003, 2006) and Wadas (2007), higher starch and dry mass contents were found in tubers cultivated under agro-textile and perforated plastic film in comparison to tubers cultivated without any cover.

From the point of view of agricultural practice, costeffectiveness is an important factor in the assessment of technologies for plant production. The application of coverings increases the investment required (Pszczółkowski et al. 2001), which is why its can be justified only in cases where the value of the harvest increment exceeds the expenditure
Table 11 Simulation of gross margin values from potatoes harvested on various dates, with coverings used over 3 years

\begin{tabular}{clllll}
\hline Cover type & $\begin{array}{l}\text { Harvest date }- \\
\text { days after planting }\end{array}$ & $\begin{array}{l}\text { Commercial } \\
\text { yield }\left(\mathrm{t} \mathrm{ha}^{-1}\right)\end{array}$ & $\begin{array}{l}\text { Value of production } \\
\left(\mathrm{PLN} \mathrm{ha}^{-1}\right)\end{array}$ & $\begin{array}{l}\text { Direct costs } \\
\left(\mathrm{PLN} \mathrm{ha}^{-1}\right)\end{array}$ & $\begin{array}{l}\text { Gross margin } \\
\left(\mathrm{PLN} \mathrm{ha}^{-1}\right)\end{array}$ \\
\hline $\begin{array}{c}\text { Control } \\
\text { treatment }\end{array}$ & 60 & 6.61 & 13,220 & 6700 & 6520 \\
& 75 & 12.34 & 12,340 & 6700 & 5640 \\
Agro-textile & 60 & 18.54 & 9270 & 6900 & 2370 \\
& 75 & 8.46 & 16,920 & 8324 & 8596 \\
& Full maturity & 15.22 & 15,220 & 8324 & 6896 \\
Perforated & 60 & 18.59 & 9295 & 8524 & 771 \\
plastic film & 75 & 8.99 & 17,980 & 8490 & 9490 \\
& Full maturity & 13.63 & 13,630 & 8490 & 5140 \\
& 15.86 & 7930 & 8690 & -760 \\
\hline
\end{tabular}


incurred (Rembeza 2002; Wadas 2007). The direct costs of potato cultivation in our study were $24-27 \%$ higher under perforated plastic film and agro-textile covers over three seasons as compared to the reference cultivation. Other authors have also pointed out that the direct costs of cover use may be decreased by using the covers for several years (Harasim et al. 2004; Wadas 2003; Wadas and Sawicki 2005). Our study demonstrates the low cost-effectiveness or total lack economic benefit of applying covers for the cultivation of potatoes harvested at full physiological maturity. High gross margin values were, however, obtained on the 60th and 75th days after planting under perforated plastic film and agro-textile covers, which may therefore be recommended for the cultivation of potatoes intended for early cropping.

\section{Conclusions}

1. In the potato cultivation under agro-textile cover higher tuber yields, both total and commercial, were obtained on average for each harvest time, while lower yields were obtained from potato cultivation without cover.

2. Higher starch content and increased dry mass were noted in potato tubers cultivated under cover in comparison to potatoes cultivated without covering.

3 . The proportions of tuber fractions with a diameter of 4.6$5.5 \mathrm{~cm}$ and above in the total yield were significantly affected by cover type. A significantly lower proportion of these fractions was observed under plastic film than under Agro-textile. 4. The highest gross margin values were obtained for potatoes harvested on the 60th day after planting in the plot covered with perforated plastic film, for potatoes harvested on the 75th day after planting in the cultivation under agro-textile cover and in the control for potatoes harvested at their full physiological maturity. The harvest of potatoes grown under perforated plastic film at their full physiological maturity was not cost-effective.

Acknowledgments The authors would like thank very much Mr. John Richard Speller for the most valuable comments and editing job on the manuscript.

Open Access This article is distributed under the terms of the Creative Commons Attribution License which permits any use, distribution, and reproduction in any medium, provided the original author(s) and the source are credited.

\section{References}

Augustyńska-Grzymek, I., L. Goraj, S. Jarka, T. Pokrzywa, and A. Skarżyńska. 2000. Methology for the calculation of gross margin and principle of farm typology, 1-55. Warszawa: FAPA.

Bizer, E. 1994. Frühkartoffelanbau unter Vlies und Folie. Kartoffelbau 45: 462-466.
Cholakov, T.L., and E.K. Nacheva. 2009. Results from using polypropylene cover in production of early potatoes. Acta Horticulturae (ISHS) 830: 603-608.

Collingwood, C.I., and S. Frost. 1988. Some environmental consequences of groundsheets on campsite vegetation. International Journal of Environmental Studies 32(2-3): 217-223.

Demmler, D. 1998. Vergleich von Folie und Vlies zur Ernte verfrühung in Fruhkartoffeln. Kartoffelbau 49: 429-430.

Dvořák, P., and K. Hamouz. 2008. Yield of early potatoes as depended on the term of nonwoven textile removement. Zeszyty Problemowe Postepów Nauk Rolniczych 530: 235-240.

Friessleben, R. 1984. Untersuchungen zum Anbau von Speisefrühkartoffeln unter perforierter Polyethylenefolie. Archiv Acker Pflanzenbau Bodenkunde 28(2): 133-142.

Gładysiak, S., and F. Borówczak. 1996. Influence of weather, sprinkling and nitrogen fertilization on the yields of potatoes in many-year experiments in Wielkopolska conditions. Zeszyty Problemowe Postepów Nauk Rolniczych 438: 53-60 (in polish).

Hamouz, K., P. Dvořak, J. Čepl, and V. Pivec. 2005. The effect of polypropylene fleece covering on the yield of early potatoes. Horticultural Science (Prague) 32(2): 56-59.

Harasim, A., P. Pszczółkowski, and B. Sawicka. 2004. The possibilities to influence the production effectiveness of early potatoes through improvements of crop management. Annales UMCS, Sec. E 59(1): 241-249. in polish.

Jabłońska-Ceglarek, R., and W. Wadas. 2005. Effect of nonwoven polypropylene covers on early tuber field of potato crops. Plant, Soil and Environment 51(5): 226-231.

Jenkins, P.D., and T.C. Gillison. 1995. Effect of plastic film covers on dry-matter production and early tuber yield of potato crops. The Annals of Applied Biology 127(1): 201-213.

Prośba-Białczyk, U., and M. Mydlarski. 1998. Growth potato on early harvest under cover with polypropylene sheets. Fragmenta Agronomica 1(57): 74-84 (in polish).

Pszczółkowski, P., A. Harasim, and B. Sawicka. 2001. Economic performance of the production technologies for early consumption potaoes harvested on different dates. Roczniki Nauk Rolniczych, Ser. G 89(1): 89-99 (in polish).

Rębarz, K. 2013. Effect of irrigation, method of emergence forcing and nitrogen fertilization on yield and quality of very early potato tubers. Monograph. UP, Poznań. ISBN: 978-83-7160-697-7 (in polish).

Rębarz, K., and F. Borówczak. 2006. Production and economic effects of various cultivation intensity of the Bila cultivar potatoes. Zeszyty Problemowe Postepów Nauk Rolniczych 511 cz II: 469-479.

Regulation of the Minister of Agriculture and Rural Development 29 October 2003. Dz. U. 2003 r. nr 194, item 1900.

Rembeza, J. 2002. Conditions of economic inputs efficiency in potato production. Pam. Put. 130(2): 625-633 (in polish).

Sawicka, B. 1998. Technological and economical effects of cultivation of early potato varieties under polyethylene sheeting. Roczniki Akademii Rolniczej w Poznaniu CCCVII Rolniczych 52: 175-182 (in polish).

Shock, C., Z. Holmes, T. Stieeber, E. Eldredge, and P. Zhang. 1993. The effect of timed water stress on quality, total solides and reducing sugar content of potatoes. American Potato Journal 70: 227-241.

Storey, R.M.J., and H.V. Davies. 1992. Tuber quality. In The potato crop, ed. P.M. Har-Risl, 507-552. London: Chapman \& Hall.

Wadas, W. 2003. The economic effectiveness of early potato production under agrotextile covers. Pam. Put. 133: 207-214 (in polish).

Wadas, W. 2007. Use of plastic covers in potato cultivation for early crop. Postepów Nauk Rolniczych 2: 71-85 (in polish).

Wadas, W., and M. Sawicki. 2005. Estimation of early potato production profitability in the mind-eastern Poland conditions. Pam. Put. 139: 289-297 (in polish). 
Wadas, W., and M. Sawicki. 2009. The economic effectiveness of early potato production depending on the kind of cover. Polish Journal of Agronomy 1: 56-61.

Wadas, W., R. Jabłońska-Ceglarek, and E. Kosterna. 2003. Analysis of costs of eary potato production under agrotextille covers. Zeszyty Naukowe AP Siedlcach, Rolnictwo 63: 91-97 (in polish).

Wadas, W., E. Kosterna, and T. Żebrowska. 2006. The effect of using covers in cultivation of early potato cultivars on the content of some nutrients in tubers. Zeszyty Problemowe Postepów Nauk Rolniczych 511(I): 233-243 (in polish).

Xiao-Ling, W., L. Feng-Min, J. Yu, and S. Wen-Quan. 2005. Increasing potato yields with additional water and increased soil temperature. Agricultural Water Management 78: 181-194.

Xiao-Yan, H., W. Feng-Xin, H. Jiang-Jiang, K. Shao-Zhong, and F. ShaoYuan. 2010. Duration of plastic mulch for potato growth under drip irrigation in an arid region of Northwest China. Agricultural and Forest Meteorology 150: 115-121.

Yusuph, M., F. Tester, A. Colin, and E. Snape. 2003. Composition and properties of starches extracted from tubers of different potato varieties grown under the same environmental conditions. Food Chemistry 82: 283-289.

Zaag, D.E. 1980. Potatoes and their cultivation in the Netherlands. Netherlands potato consultative institute and the ministry of agriculture and fisheries foreign information service. Publication E 108: 175.

Zimnoch-Guzowska, E., and B. Flis. 2006. Inheritance of the quality traits in potato. Zeszyty Problemowe Postepów Nauk Rolniczych.I. 511: 23-36 (in polish). 